\title{
Multivariate Statistical Analysis of Groundwater Mineralization in Daloa and Zoukougbeu, Central West, Côte d'Ivoire
}

\author{
${ }^{* 1}$ ADJIRI, OA; ${ }^{1}$ SORO, TD; ${ }^{2}$ SORO, G; ${ }^{3}$ AKA, N; ${ }^{2}$ SORO, N \\ ${ }^{1}$ Laboratory of Environnemental Sciences and Technologies (LSTE), UFR ENVIRONNEMENT, Jean Lorougnon GUÉDÉ University, BP \\ 150 Daloa Côte d'Ivoire 25 B.P 97 Cidex 1 Abidjan, 25, Tél/Cél: (225) 224332 38/ 076029 06, \\ *Corresponding Author Email: oiadjiri@gmail.com \\ ${ }^{2}$ Laboratory of Water and Environmental Sciences and Techniques (LSTEE), UFR SRTM, Félix Houphouët Boigny University, 22 B.P. 582 \\ Abidjan 22, Côte d'Ivoire \\ ${ }^{3}$ Laboratory of Physics and Marine Geology, Oceanological Research Center of Abidjan (CRO), BP V18 Abidjan, Côte d'Ivoire
}

\begin{abstract}
This study aims to determine the mechanisms of groundwater mineralization in the departments of Daloa and Zoukougbeu (Central West, Côte d'Ivoire). In order to achieve this, a hydrochemical study was carried out from seventeen (17) water samples (wells and sources) collected in March 2018. It was based on the multivariate statistical analysis techniques: The Principal Component Analysis (PCA) and the Hierarchical Cluster Analysis (HCA) were applied to physicochemical parameters. Thus, the average values of temperature, $\mathrm{pH}$, electrical conductivity, Total Dissolved Solids (TDS) and Turbidity measured in situ in source waters are respectively $27.63^{\circ} \mathrm{C} ; 4.81 ; 84.6 \mu \mathrm{S} / \mathrm{cm} ; 38.45 \mathrm{mg}$. L ${ }^{1}$ and $40.78 \mathrm{NTU}$ and in well water $27.90^{\circ} \mathrm{C} ; 4.78 ; 81.85 \mu \mathrm{S} / \mathrm{cm} ; 36.61 \mathrm{mg}$. $\mathrm{L}^{-1}$ and $27.22 \mathrm{NTU}$. The average concentrations of the major cations $\mathrm{Ca}^{2+}, \mathrm{Mg}^{2}, \mathrm{Na}^{+}$and $\mathrm{K}^{+}$of well water are respectively $2.26 ; 1.01 ; 4.58 ; 1.41 \mathrm{mg}$. $\mathrm{L}^{-1}$ and those of spring waters $2.18 ; 1.03 ; 5.50$ and $2.07 \mathrm{mg} . \mathrm{L}^{-1}$. The major anions $\mathrm{HCO}_{3}{ }^{-}, \mathrm{Cl}^{-}, \mathrm{SO}_{4}{ }^{2-}$ and $\mathrm{NO}_{3}{ }^{-}$respectively amount to $8.81 ; 8.28$; 5.33 and $7.67 \mathrm{mg} . \mathrm{L}^{-1}$ for well water and $11.77 ; 8.5 ; 5.27$ and $8.25 \mathrm{mg} . \mathrm{L}^{-1}$ for spring waters. The PCA results show that three phenomena govern the mineralization of these waters. These are the phenomena of mineralization-residence time of water which is acquired by acid hydrolysis of the host rocks, spatial origin of lower quality of water and the grounds throughfall. These phenomena are confirmed by the Hierarchical Cluster Analysis (HCA). This work is therefore a tool for supporting groundwater management.
\end{abstract}

\section{DOI: https://dx.doi.org/10.4314/jasem.v23i8.2}

Copyright: Copyright (C) 2019 Adjiri et al. This is an open access article distributed under the Creative Commons Attribution License (CCL), which permits unrestricted use, distribution, and reproduction in any medium, provided the original work is properly cited.

Dates: Received: 09 March 2019; Revised: 21 July 2019; Accepted 29 July 2019

Keywords: Groundwater, Mineralization, PCA, HCA, Central West, Côte d'Ivoire

Groundwater are the main source of drinking water supply due to scarcity and / or exposure to surface water pollution. They are exploited from various works: wells, boreholes, etc. (De Marsily et al., 2017). They were by far the least exposed resource to pollution. Unfortunately, nowadays, they are threatened with more and more contamination. On the other hand, in Africa, the difficulties of people's access to drinking water further complicate the achievement of the millennium goals for sustainable development. Like most Ivorian regions, the Central West is not spared despite the good rainfall (Adjiri et al., 2019). In the departments of Daloa and Zoukougbeu, surface water is in quantity, but the problems of quality, portability and continuity of service occur (Koukougnon, 2013). The only alternative to supply population with drinking water, especially in rural areas, is the exploitation of groundwater. In urban areas, it will provide good quality of water and less expensive. To do this, the knowledge of the functioning of aquifers is undeniable. This operation can be perceived by studying the mechanisms that govern waters mineralization contained in these aquifers. Indeed, the study of the hydrogeochemical processes is of capital interest to appreciate the quality of a region's groundwater. In fact, the variation and / or the presence of certain chemical parameters can reveal the interactions between water and its environment and can guide on the management methods to be implemented ( $\mathrm{Li}$ et al., 2018). In addition, multivariate statistical analysis techniques have been used successfully in several hydrochemical studies. Montcoudiol et al. (2015), used these techniques in the Outaouais region, southwestern Quebec, to identify the processes that govern groundwater chemistry. In the Amacuzac River basin in central Mexico, Eric et al. (2016) used multivariate statistical analysis to search for geochemical evolution of groundwater. Benadela and Bekoussa (2017) also used multivariate statistical methods to study groundwater mineralization of the Ghriss plain in northwestern Algeria. It is in this context that the 
present study fits. It plans to investigate groundwater mineralization mechanisms in the departments of Daloa and Zoukougbeu, using multivariate statistical analysis tools such as Principal Component Analysis (PCA) and Hierarchical Cluster Analysis (HCA). Recall that various authors (Everitt and Hothorn, 2010, Eric et al., 2016) have indicated in their work that Principal Component Analysis (PCA) is generally used as a diagnostic tool to identify trends in geochemical data.

Study Area: The study area includes the departments of Daloa and Zoukougbeu, located in Côte d'Ivoire's central west. It lies between longitudes $6^{\circ}$ and $7^{\circ} \mathrm{West}$ and latitudes $6^{\circ}$ and $7^{\circ}$ North (Figure 1).

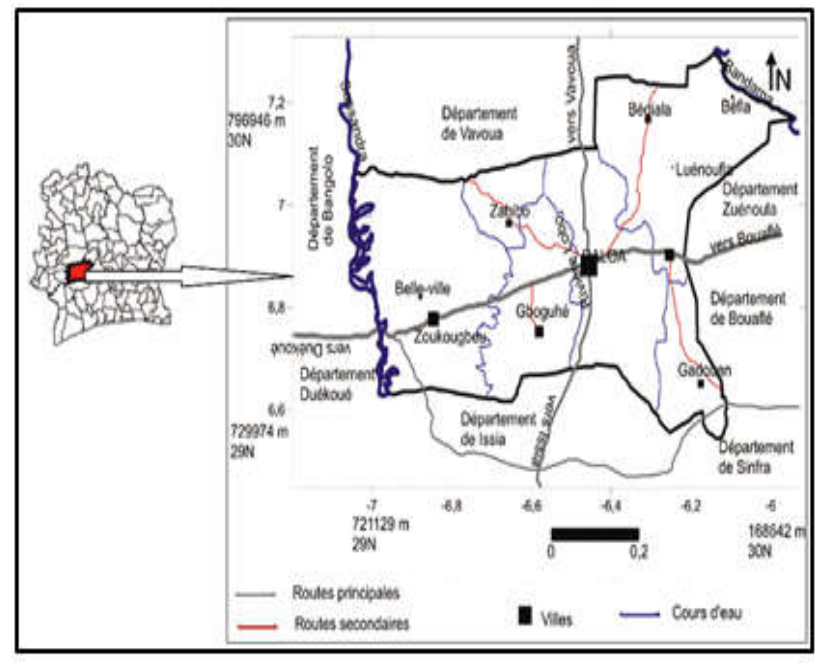

Fig 1: Location of the study area

It therefore belongs to the region of Haut Sassandra with chief town of region, Daloa. The city of Daloa is located at $383 \mathrm{~km}$ from Abidjan, the economic capital of the country. It is a forest area that is now degraded due to agricultural activities and logging. Soils are remodeled and hydromorphic types (Tahoux, 1995). The formers occupy more than $90 \%$ of the area and are generally derived from the granites' alteration. They are characterized by gravels in the upper part (Tahoux, 1995). The weathering patterns of these soils are mainly of the ferrallitic type with persistence of iron and aluminum in the form of oxides and hydroxides. This type of soil is favorable for many crops such as cocoa and coffee. As for the hydromorphic soils, these are observed along the rivers and in the shallows. These are soils that have a high capacity for water conservation and are generally used for rice growing and market gardening (Ligban, 2009). The departments of Daloa and Zoukougbeu belong to the West African climate regime characterized by the action of two air masses of different natures. It is the harmattan marked by warm and dry air, brought by the boreal trade winds that blow from the north-east to the south and the monsoon characterized by the cold and humid air coming from the Atlantic Ocean under the effect of the Southern trade wind and circulating from the South to the northeast. With annual rains dropped from $1868.5 \mathrm{~mm}$ in 1968 to $1120.4 \mathrm{~mm}$ in 2005 , the region is experiencing a $40 \%$ drop in rainfall (Ligban, 2009). The average annual temperature recorded at Daloa station is $25.8^{\circ} \mathrm{C}$ with monthly variations generally below $3^{\circ} \mathrm{C}$. The hydrographic system is dense with the Sassandra River which is the main river that regulates the hydrography of the zone. The river system attached to its bed is dominated by the Lobo and Davo rivers, which are respectively in the central and southeastern parts. Regional drainage occurs in north-south direction. Geologically, the main formations encountered are granitoids, dioritoids and shales. At the hydrogeological level, there are two types of aquifers: the aquifer of regolith and the aquifers of cracks.

\section{MATERIAL AND METHODS}

Material: The field equipment for the measurement of physicochemical parameters in situ consists of a HACH HQ40d multiparameter, a distilled water bottle, distilled water and nitric acid. For water sampling, we used 1-liter bottles of polyethylene and three coolers for sample retention. Garmin GPS was used for geolocation of water points.

Sampling methodology: Two water sampling campaigns were carried out in March 2018. They 
covered 17 water points including 11 sources and 6 large-diameter wells with an average depth of $8 \mathrm{~m}$. During sampling, the following procedures were followed: the bottles, previously rinsed with distilled water, are rinsed 3 times with the water to be analyzed, then filled to the brim and tightly closed without leaving any bubbles. Once the bottles are filled, they are kept in a cooler to maintain a low temperature of $4^{\circ} \mathrm{C}$. That avoids the degassing of water and the precipitation of certain chemical elements. Two samples were taken for each source, one for anion dosage and another for cation dosage. The analyses were performed 48 hours after taking samples. The contents of major ions (cations and anions) were determined using a colorimeter and a HACH-type digital titrator for anions and an atomic emission spectrometer (ICP-AES) whose source is plasma generated by inductive coupling for cations. To this end, we used various reagents and laboratory accessories. The turbidities were measured by a turbidimeter brand HACH 21000.
Data processing method: multivariate statistical analysis: Multivariate statistical analysis is a quantitative and independent approach to groundwaters classification to group samples and correlate chemical parameters with water samples. In this study, two methods of multivariate statistical analysis were used from the Statistica software 7.1: Principal Component Analysis (PCA) and Hierarchical Cluster Analysis (HCA).

\section{RESULTS AND DISCUSSION}

Basic statistics of physical parameters: Table 1 presents the results of basic statistics of the physical parameters measured in situ in the groundwater of the departments of Daloa and Zoukougbeu. The analysis of the results in table 1 shows that for spring waters, the TDS values are between 15.33 and $100.2 \mathrm{mg}$. $\mathrm{L}^{-1}$ for an average of $38.45 \mathrm{mg}$. $\mathrm{L}^{-1}$ and a standard deviation of 25.01 . The minimum temperature is $26.2^{\circ} \mathrm{C}$ against $29.3^{\circ} \mathrm{C}$ for its maximum value with an average of $27.63^{\circ} \mathrm{C}$. The $\mathrm{pH}$ is between 4.38 and 5.91 for an average of 4.81 .

Table 1: Summary of basic statistics of physical parameters measured in situ

\begin{tabular}{|c|c|c|c|c|c|c|}
\hline \multicolumn{7}{|c|}{ Source Water } \\
\hline Parameters & Units & VG & Min & Max & Avg & Standard Deviation \\
\hline TDS & $\mathrm{mg} \mathrm{L}^{-1}$ & & 15.33 & 100.2 & 38.45 & 25.01 \\
\hline $\mathbf{T}$ & ${ }^{\circ} \mathrm{C}$ & $22-25$ & 26.2 & 29.3 & 27.63 & 1.3 \\
\hline pH & & 6.5 à 9.5 & 4.38 & 5.91 & 4.81 & 0.46 \\
\hline CE & $\mu \mathrm{S} / \mathrm{cm}$ & 1400 & 33.7 & 218.9 & 84.6 & 54.46 \\
\hline Turbidity & NTU & 5 & 1.24 & 146 & 40.78 & 47.70 \\
\hline \multicolumn{7}{|c|}{ Well Water } \\
\hline TDS & $\mathrm{mg} \mathrm{L}^{-1}$ & & 25 & 48.8 & 36.61 & 7.98 \\
\hline $\mathbf{T}$ & ${ }^{\circ} \mathrm{C}$ & $22-25$ & 26.8 & 28.7 & 27.90 & 0.68 \\
\hline pH & & 6.5 à 9.5 & 4.02 & 5.14 & 4.78 & 0.42 \\
\hline CE & $\mu \mathrm{S} / \mathrm{cm}$ & 400 & 57.6 & 111.2 & 81.85 & 18.05 \\
\hline Turbidity & NTU & 5 & 1.37 & 67.8 & 27.22 & 28.13 \\
\hline
\end{tabular}

The electrical conductivity values range from 33.7 to $218.9 \mu \mathrm{S} / \mathrm{cm}$ for an average of $84.6 \mu \mathrm{S} / \mathrm{cm}$. As for the turbidity values, they are between 1.24 and 146 NTU for an average of 37.78. For well waters, the TDS values are between 25 and $48.8 \mathrm{mg}$. $\mathrm{L}^{-1}$ for an average of $36.61 \mathrm{mg}$. $\mathrm{L}^{-1}$. As for the temperature values, they range from $26.8^{\circ} \mathrm{C}$ to $28.7^{\circ} \mathrm{C}$ with an average of $27.90^{\circ} \mathrm{C}$. The minimum $\mathrm{pH}$ is 4.02 for a maximum value of 5.14 and an average of 4.78 . The minimum electrical conductivity is $57.6 \mu \mathrm{S} / \mathrm{cm}$ against a maximum value of $111.2 \mu \mathrm{S} / \mathrm{cm}$ for an average of $81.85 \mu \mathrm{S} / \mathrm{cm}$. The minimum turbidity is $1.37 \mathrm{NTU}$ against a maximum value of $67.8 \mathrm{NTU}$ and an average of 27.22 NTU. With the exception of turbidity, these values are for the most part lower than the WHO guideline values (2011). These values indicate that waters are mostly acidic, weakly mineralized. The strong turbidities observed in some places are probably related to the lithological nature of aquifers and/or the presence of organic materials. Turbidity is one of the parameters used to characterize water quality. According to the definition given by standard NF EN ISO 7027 of March 2000, it is defined as the reduction of the transparency of a liquid due to the presence of undissolved materials.

Basic statistics of chemical parameters: Table 2 presents the results of the basic statistics of the chemical parameters dosed in laboratory. The minimum and maximum concentrations of hydrogen carbonate ions, chlorides, nitrates and sulphates are respectively 0.73 and $36.6 \mathrm{mg} / \mathrm{L} ; 2.4$ and $16 \mathrm{mg} / \mathrm{L} ; 0.5$ and $38.07 \mathrm{mg} / \mathrm{L} ;<\mathrm{LD}$ and $14 \mathrm{mg} / \mathrm{L}$. The average contents are respectively $10.30 ; 8.41 ; 7.86 ; \approx 5.29$ $\mathrm{mg} / \mathrm{L}$. At cations level, the minimum and maximum concentrations of calcium, magnesium, potassium and sodium ions are respectively 0.4 and $9.2 ;<\mathrm{LD}$ and $3.17 ; 0.41$ and $6.67 ; 1.33$ and 12.5 . The average 
contents are respectively $2.18 ; \approx 1.01 ; 1.89$ and 5.14 $\mathrm{mg} / \mathrm{L}$. These concentrations are all below the WHO guideline values (2011). However, bicarbonate seems to be the most concentrated, with contents in spring waters, about twice that of well water. The latter is followed by nitrate, relatively in the same proportions in the two resources. In terms of the other ions, the levels are relatively similar, both in spring water and in wells.

Results of multivariate statistical analysis: Principal Component Analysis (PCA): Analysis of eigenvalues and percentages expressed: The results of eigenvalues and percentages of expressed variance for the first four factors are shown in Table 3 .
The table analysis shows that the first four factors account for $86.67 \%$ of the total variance. The first three factors alone account for more than $70 \%$ of the expressed variance. The factor F1 alone accounts for $44.59 \%$ of the variance, followed by the factor F2 with $18.71 \%$ and F3 with $14.46 \%$. In view of these expressed percentages, we can say that the mechanisms that control the chemical evolution of waters in the region are largely contained in these three factors. As a result, our analysis will focus solely on these three factors. The eigenvectors that make it possible to define each of these three factors in relation to the variables are reported in Table 4 .

\begin{tabular}{|c|c|c|c|c|c|c|c|c|}
\hline Parameters & $\begin{array}{l}\mathrm{Ca}^{2+} \\
(\mathrm{mg} / \mathrm{L})\end{array}$ & $\begin{array}{l}\mathrm{Mg}^{2+} \\
(\mathrm{mg} / \mathrm{L})\end{array}$ & $\begin{array}{l}\mathrm{Na}^{+} \\
(\mathrm{mg} / \mathrm{L})\end{array}$ & $\begin{array}{l}\mathrm{K}^{+} \\
(\mathrm{mg} / \mathrm{L})\end{array}$ & $\begin{array}{l}\mathrm{HCO}_{3}{ }^{-} \\
(\mathrm{mg} / \mathrm{l})\end{array}$ & $\begin{array}{l}\mathrm{Cl}^{-} \\
(\mathrm{mg} / \mathrm{L})\end{array}$ & $\begin{array}{l}\mathrm{SO}_{4}^{-2} \\
(\mathrm{mg} / \mathrm{L})\end{array}$ & $\begin{array}{l}\mathrm{NO}_{3}^{-} \\
(\mathrm{mg} / \mathrm{L})\end{array}$ \\
\hline \multicolumn{9}{|l|}{ Source Water } \\
\hline Minimum & 0.8 & 0.24 & 2.43 & 0.75 & 5.12 & 4.4 & 1 & 0.5 \\
\hline Maximum & 9.2 & 3.17 & 12.5 & 3.31 & 36.6 & 16 & 14 & 38.07 \\
\hline Average & 2.36 & 1.08 & 5.36 & 1.62 & 12.71 & 8.45 & 5.3 & 8.91 \\
\hline \multicolumn{9}{|l|}{ Well Water } \\
\hline Minimum & 0.4 & $<\mathrm{LD}$ & 1.33 & 0.41 & 0.73 & 2.4 & $<\mathrm{LD}$ & 1.7 \\
\hline Maximum & 5.6 & 2.93 & 7.46 & 6.67 & 19.89 & 13.5 & 9 & 14.61 \\
\hline Average & 2.00 & $\approx 0.94$ & 4.92 & 2.16 & 7.89 & 8.38 & $\approx 5.28$ & 6.82 \\
\hline WHO guideline values* & 70 & 50 & 200 & 12 & 200 & 250 & 250 & 50 \\
\hline
\end{tabular}

Table 3: Eigen values and percentage expressed

\begin{tabular}{lllll}
\hline & F1 & F2 & F3 & F4 \\
\hline Eigen value & 5.80 & 2.43 & 1.88 & 1.16 \\
\% Expressed variance & 44.59 & 18.71 & 14.46 & 8.91 \\
\% Cumulative expressed variance & 44.59 & 63.31 & 77.76 & 86.67 \\
\hline
\end{tabular}

Factorial plan analysis F1-F2:_The correlation circle of the factorial plan F1-F2 (Figure 2) shows that the factor $\mathrm{F} 1$ with $44.59 \%$ variance is determined in its positive part by the group of variables $\mathrm{Ca}^{2+}, \mathrm{Mg}^{2+}, \mathrm{Na}^{+}$, $\mathrm{Cl}^{-}$, electrical conductivity (CE) and TDS. Sulphates $\left(\mathrm{SO}_{4}{ }^{2-}\right)$ are opposed to these variables in the negative part. Variables such as $\mathrm{Ca}^{2+}, \mathrm{Mg}^{2+}$ are generally derived from rock alteration and acid hydrolysis of silicate minerals. This phenomenon is a slow process, especially in fissure aquifers where water flow velocities are low due to a poorly developed fracture network in the basement region.

The factor F1 accounts for the mineralization acquisition conditions. It expresses the phenomenon of mineralization-residence time of waters in the aquifer. The F2 factor with $18.71 \%$ variance is expressed in its positive part by the nitrates $\left(\mathrm{NO}_{3}{ }^{-}\right)$and the $\mathrm{pH}$ and $\mathrm{T}^{\circ} \mathrm{C}$ variables in its negative part.

The variable $\mathrm{NO}_{3}$-reflects the nitrogen pollution of water. Its presence in groundwater is an indicator of the impact of anthropogenic activities such as the use of fertilizers in agriculture, wild garbage dumps and often litter. They reach the water table by infiltration per descendant.

Table 4: Coordinates of variables according to factorial

\begin{tabular}{|c|c|c|c|}
\hline \multicolumn{4}{|c|}{ axes } \\
\hline & Fact. 1 & Fact. 2 & Fact. 3 \\
\hline TDS & 0.961845 & 0.199141 & 0.003940 \\
\hline $\mathrm{T}^{\circ} \mathrm{C}$ & 0.089105 & -0.724996 & 0.362815 \\
\hline $\mathrm{pH}$ & 0.259594 & -0.709261 & -0.485332 \\
\hline $\mathrm{CE}$ & 0.960708 & 0.216929 & 0.016317 \\
\hline Turb & -0.454350 & 0.307444 & -0.664276 \\
\hline $\mathrm{Ca}^{2+}$ & 0.809508 & 0.277862 & -0.295396 \\
\hline $\mathrm{Mg}^{2+}$ & 0.836179 & -0.150294 & -0.360831 \\
\hline $\mathrm{Na}^{+}$ & 0.778750 & -0.383183 & -0.020309 \\
\hline $\mathrm{K}^{+}$ & 0.453646 & -0.374702 & 0.259995 \\
\hline $\mathrm{HCO}_{3}{ }^{-}$ & 0.159292 & -0.470407 & -0.774384 \\
\hline $\mathrm{Cl}^{-}$ & 0.817413 & 0.195310 & 0.155805 \\
\hline $\mathrm{SO}_{4}{ }^{2-}$ & -0.617853 & 0.296159 & -0.397001 \\
\hline $\mathrm{NO}_{3}^{-}$ & 0.652244 & 0.698898 & -0.058561 \\
\hline
\end{tabular}

On the other hand, the relative opposition of the $\mathrm{Ca}^{2+}$, $\mathrm{Mg}^{2+}, \mathrm{Na}^{+}, \mathrm{Cl}^{-}, \mathrm{CE}$ and TDS variables to $\mathrm{pH}$ and temperature would reflect the influence of the latter respectively on the acquirement of mineralization and water degradation. In total, the factor F2 expresses the phenomenon spatial origin of water quality degradation. 


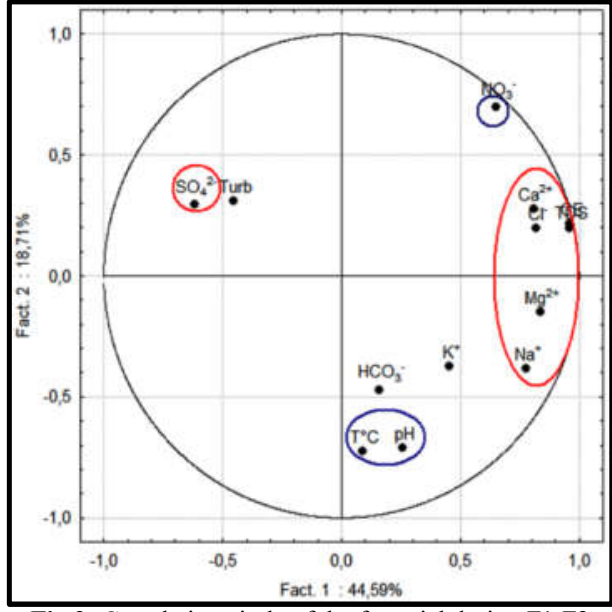

Fig 2: Correlation circle of the factorial design F1-F2

Analysis of the factorial design F1-F3: The correlation circle of the factorial design F1-F3 (Figure 3) reveals that $\mathrm{F} 1$ factor is controlled in its positive side by the group of variables such as $\mathrm{Ca}^{2+}, \mathrm{Mg}^{2+}, \mathrm{Na}^{+}, \mathrm{Cl}^{-}, \mathrm{NO}_{3}{ }^{-}$, the electrical conductivity (CE) and TDS which is always in opposition with the $\mathrm{SO}_{4}{ }^{2-}$ variable.

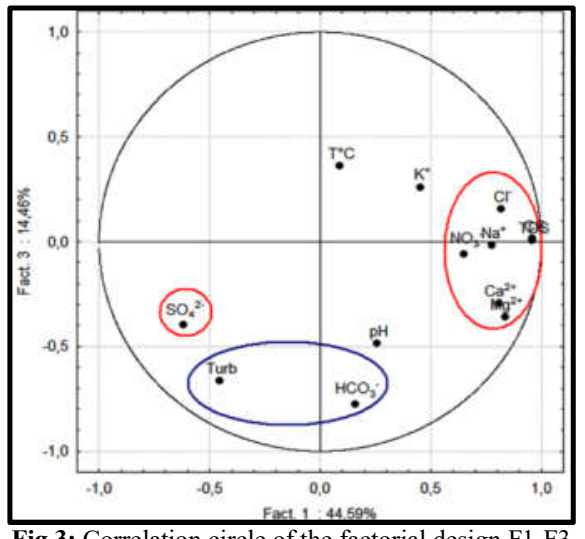

Fig 3: Correlation circle of the factorial design F1-F3

F1 expresses the phenomenon residence time mineralization in the aquifer waters. With $14.46 \%$ of variance, the F3 fact is determined in its negative side by the group of Turbidity variable (Turb) and content in $\mathrm{HCO}_{3}{ }^{-}$. This fact reveals that the turbidity of groundwater will be generally inorganic (limon, silt, clay and natural chemical components) and therefore caused by natural geological factors. This design then highlights superficial exchanges which occurred between groundwater and runoff waters coming from precipitation and soil drainage. These exchanges bring to light the throughfall of soils that contribute to the increase of the number of particles in the water bodies. The F3 fact therefore expresses a phenomenon of soils' throughfall surrounding water points.
Hierarchical Cluster Analysis (HCA): The dendrogram coming from the ascending hierarchical classification helps to define three major groups of variables. The first one is formed by the following variables: $\mathrm{pH}, \mathrm{Na}^{+}, \mathrm{Ca}^{2+}, \mathrm{Mg}^{2+}, \mathrm{K}^{+}, \mathrm{Cl}^{-}, \mathrm{SO}_{4}{ }^{2-}, \mathrm{NO}_{3}{ }^{-}$ and $\mathrm{HCO}_{3}{ }^{-}$. This group of variables shows the residence time mineralization or the hydrolysis of carbonate or silicate minerals after an extension of water residence times in the aquifer. The second one is comprised of temperature and the TDS reveals the influence of temperature in the process of acquisition and mineralization. The third and last one includes the $\mathrm{CE}$ and the turbidity. This group highlights the phenomenon of soils' throughfall. In fact, as already explained at the level of PCA, the groundwater turbidity will generally be inorganic and caused by natural geological factors. This group of variables confirms that finding and effectively reflects the soils' throughfall.

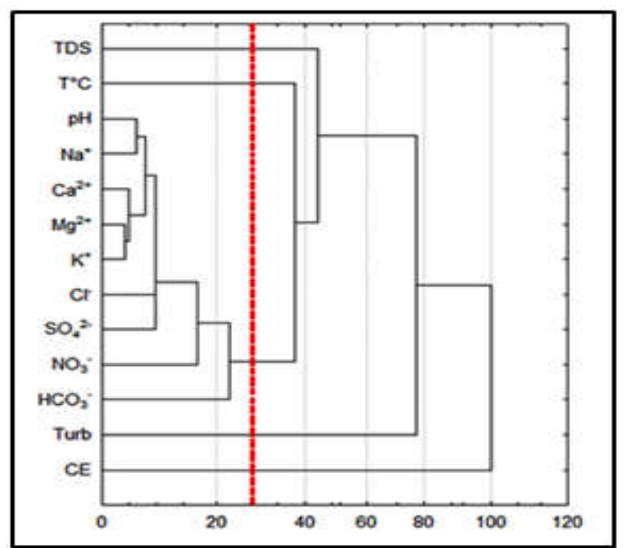

Fig 4: Horizontal dendrogram of waters study area

The results of basic statistics demonstrate that the average $\mathrm{pH}$ of well and spring waters are respectively 4.78 and 4.81 . The $\mathrm{pH}$ value interval recommended by WHO (2011) is 6.5-9.5. The value of the obtained average $\mathrm{pH}$ are in total below 6.5. These waters are then acids. The acid nature of these waters is may be the result of an anthropogenic and biogeochemical process. This process is governed by the soil $\mathrm{CO}_{2}$ generated through the breathing of plant roots and the decomposition of organic plant material. (Kortatsi, 2006; Kortatsi, 2007; Kortatsi et al., 2008, Matini et al., 2009). In fact, the presence of forests and a rainfall relatively abundant in the Ivorian Central West area causes the decomposition of organic material. According to Prasad and Narayana (2004), the decomposition of organic material inside soil in aerobic environment emits carbon dioxide. This latter dissolves in water in order to form a carbonic oxide following this chemical reaction $\mathrm{CH}_{2} \mathrm{O}+\mathrm{O}_{2} \rightleftarrows \mathrm{CO}_{2}+$ 
$\mathrm{H}_{2} \mathrm{O} \rightleftarrows \mathrm{H}^{+}+\mathrm{HCO}_{3}^{-}$. According to these authors, this reaction illustrates the origin of the acid nature of waters. Ligban et al. (2009) and Adjiri et al. (2018) noted that acid nature of groundwater in the HautSassandra area.

On the other hand, turbidity is one of the parameters which allows the characterization of water quality. According to the statistical analysis undertaken (PCA), the high turbidity measured in the spring as well as in well waters are linked to the geological nature of aquifers. Indeed, the identified wells and springs mostly came from shallow aquifers. (Adjiri et al., 2018). These aquifers are all regolith aquifers rich in clay. The run-off of this clay materials by rainwater would contribute to increase the fine particles load. In addition, some water points are located in shallows and cultivation area. The degradation of organic material and its run-off by rainwater also contributes to increase the turbidity of waters.

Furthermore, through the multivariate statistical analysis (PCA and HCA), the study of the origin of mineralization allowed to highlight three phenomena that will be responsible of water mineralization mechanism. These are the waters residence time mineralization, the spatial origin of water quality degradation, and soils' throughfall. The first one mainly the mineralization of groundwater according to the spent residence times in the aquifer has been revealed by Biémi (1992), Savané and Soro (2001) and Amadou et al. (2014). This has been possible through different works made on different river basins coming from the Precambrian basement of West Africa. According to these authors, the ions of the groundwater of the area concerned by their works come not only from alteration but also from the hydrolysis of silicate minerals such as biotite, silicate feldspars after a more or less longer contact time. Redwan and Moneim (2016) also make that remark in Egypt.

The second phenomenon demonstrates that the origin of the degradation of groundwater are caused by anthropic activities. In other words, waters seepage and/or of run-off coming from the washout of agricultural land are at the basis of the identified well and spring waters quality. This degradation is explained by the presence of nitrate in water. This phenomenon of mineralization by soils' throughfall has been undertaken by Hussein (2004) during his works on Blue Nil Basin's groundwater in Sudan. Concerning turbidity, it is the third phenomenon namely the soils' throughfall which may cause it.
Conclusion: This study aimed at determine the origin of groundwater mineralization in the areas of Daloa and Zoukougbeu (Central West area of Côte d'Ivoire). It focuses on the multivariate statistical tools such as PCA and HCA. The result of the basic statistics demonstrates that groundwater (well and springs) are acids with an average $\mathrm{pH}$ of 4.78 and 4.81 . These waters have low mineral content and are therefore in accordance with the chemical characteristic well recognized for groundwater in the area of base in Côte d'Ivoire. The principal component analysis (PCA) and the Hierarchical Cluster Analysis (HCA) revealed three phenomena which control groundwater mineralization. The first one was the waters residence time mineralization. The second one was the spatial origin of water quality degradation. The last one was soils' throughfall. These results represent an important database for the management and planning of groundwater resources in the areas of Côte d'Ivoire.

Acknowledgements: This research did not receive any specific grant from funding agencies in the public, commercial, or not-for-profit sectors.

\section{REFERENCES}

Adjiri, OA; Aka, N; Soro, TD ; Affessi, AC ; Konaté, D ; Soro, N (2018). Characterization of the alternative water resources in the city of Daloa: impacts on health and involvement in regional development, $T S M, N^{\circ} 12,89-114$.

Amadou, HM; Laouali, S; Manzola, S (2014). Hydrochemical characterization of groundwater in the Tahoua region (Niger). Journal of Applied Biosciences 80: 7161-7172.

Benadela, L and Bekoussa, B (2017). Of the method of multivariate analytics with the study of the mineralization of the aquifer system of Ghriss Plain (North-West Algeria). Larhyss Journal 29: 75-94.

Biémi, J (1992). Contribution to the hydrogeological geological study and remote sensing of subSaharan basins of the Precambrian basement of West Africa: hydro structural, hydrodynamic, hydro chemical and isotopic discontinuous aquifers of the furrows and granitic areas of the high Marahoué (Côte d'Ivory). Doctorate of State in Natural Sciences, University of Abidjan, Côte d'Ivoire.

Eric, MC; Belmont, JG; Ortega, GA (2016). Regional groundwater flow and geochemical evolution in the Amacuzac River basin, Mexico. Journal of Hydrogeology, 24 (7): 1873-1890. 
Everitt, BS and Hothorn, T (2010). A statistical analysis manual using R., 2nd edition.

Hussein, MT (2004). Hydro chemical assessment of groundwater in the Blue Nile Basin, eastern Sudan, using classical and multivariate techniques. Hydrogeology Journal, 12: 144-158.

Koukougnon, W (2013). Urban environment and access to drinking water: case of Daloa (Central West, Côte d'Ivoire), Félix Houphouët Boigny University, $\mathrm{PhD}$ thesis, IGT, Abidjan, Côte d'Ivoire.

Kortatsi, BK (2006). Hydro chemical characterization of groundwater in the Accra plains of Ghana. About. Geol. 50: 299-311.

Kortatsi, BK (2007). Hydro chemical framework of groundwater in the Ankobra Basin, Ghana. Aquat. Geochem. 13: 41-74.

Kortatsi, BK; Tay CK; Anornu, GE; Hayford, DGA (2008). Hydrogeochemical evaluation of groundwater in the lower Offin Basin, Ghana. About. Geol. 53(8): 1651-1662.

Li, X; Wu, H; Qian, H; Gao, Y (2018). Groundwater chemistry regulated by hydro chemical processes and geological structures: a case study in Tonchuan, China. Water, 10 (338): doi: 10.3390 / w100303338.

Ligban, R Goné, LD; Kamagaté, B; Saley, MB and Biémi, J (2009). Hydrogeochemical processes and origin of natural sources in the square degree of Daloa (Central West of Côte d'Ivoire).
International Journal of Biological and Chemical Sciences, 3 (1): 38-47.

Matini, L; Moutou, JM; Kongo-Mantono, MS (2009). Hydrochemical assessment of groundwater in urban areas south-west of Brazzaville, Congo. Africa SCIENCE 05 (1), 82-98.

Montcoudiol, N ; Molson, J ; Lemieux ; JM (2015). Groundwater geochemistry of the Outaouais Region (Quebec, Canada): a regional-scale study. Hydrogeology Journal, 23, (2): 377-396.

Prasad BG and Narayana TS (2004). Subsurface water quality of different sampling stations with some selected parameters at Machilipatnam Town. Nat. Env. Poll. Tech., 3(1): 47-50.

Redwan, M; Moneim, AAA (2016). Factors controlling groundwater hydrogeochemistry in the area west of Tahta, Sohag, Upper Egypt. Journal of African Earth Sciences, 118: 328-338.

Savané, I and Soro, N (2001). Chemical and isotopic characterization of groundwater in northwestern Côte d'Ivoire: recharge of discontinuous aquifers in the Odienné region. Africa Geoscience Review, 8 (4), 379-390.

Tahoux, TM (1995). Effects of energy systems on the environment: the case of Côte d'Ivoire. AfDB, Final Report of the African Energy Program.

WHO, (2011). Guidelines for Drinking Water Quality - 4th edition, Geneva, Switzerland. 